\title{
IMPROVING STUDENTS' SPEAKING SKILL BY USING MULTIMEDIA PRESENTATION STRATEGY
}

\author{
Muhammad Lukman Syafii \\ Department of Accounting, Faculty of Economic, Universitas Muhammadiyah Ponorogo, Indonesia \\ E-mail: s.muhammadlukman@yahoo.com
}

\begin{abstract}
Alip Sugianto
Department of Management, Faculty of Economic, Universitas Muhammadiyah Ponorogo, Indonesia E-mail: sugiantoalip@gmail.com

Nanang Cendriono

Department of Management, Faculty of Economic, Universitas Muhammadiyah Ponorogo, Indonesia E-mail: nanangcendriono@gmail.com
\end{abstract}

\begin{abstract}
APA Citation: Syafii, M. L., Sugianto, A., \& Cendriono, N. (2019). Improving students' speaking skill by using multimedia presentation strategy. English Review: Journal of English Education, 7(2), 125132. doi: $10.25134 /$ erjee.v7i2.1690.
\end{abstract}

\begin{abstract}
Multimedia presentation strategy is one of strategies that can be used for developing students' speaking skills. Therefore, this research is intended to describe how multimedia presentation strategy can improve the eighth graders' speaking skills. A collaborative classroom action research design was employed in this research. This action research was conducted in four main steps, namely planning, implementing, observing, and reflecting. To collect the data, some instruments, i.e. students' oral performance test, the observation checklist, field notes, and questionnaire, were used. The result showed that the students' speaking performance improved from $64.29 \%$ in Cycle 1 to $100 \%$ in Cycle 2. Meanwhile, the students' involvement has achieved the criteria of success (100\% of students) in Cycle 1. Here, they could fulfill at least 2 out of 4 indicators in Cycle 1 and Cycle 2. In addition, the students' perception towards the implementation of Multimedia Presentation strategy was $94.29 \%$ and only $5.71 \%$ of students who were not interested in the implementation of Multimedia Presentation strategy in teaching speaking skills. Hence, it can be concluded that Multimedia Presentation strategy can improve students' speaking skill.

Keywords: action research; multimedia presentation; speaking skill; students' involvement.
\end{abstract}

\section{INTRODUCTION}

The objective of teaching English in Indonesia based on the 2006 Standard of Content is that the students can develop their communicative competence, both in oral or written forms, to achieve a certain functional literacy stage. Hence, the four language skills including listening, speaking, reading, and writing should be taught integratedly (Pusat kurikulum, 2006).

Speaking is a productive skill that involves using speech to express meaning to other people (Spratt, Pulverness, \& Williams, 2005). Here, teachers can develop students' speaking skills by focusing regularly on a particular aspect of speaking, e.g. fluency, pronunciation, grammatical accuracy, etc. Burns and Joice (1993) argue that one of the most important aspects of speaking is that it always occurs within a context. When someone speaks, he/she is both using language to carry out various social functions and choosing forms of language which relate in a relevant way to the cultural and social context.

A large percentage of the world's language learners study English in order to develop proficiency in speaking (Richards \& Renandya, 2002). It shows that many people are aware of the importance of mastering speaking skill in order to make the students able to communicate in English with other people from other countries. Especially if they want to go abroad, it is an obligation for them to be able to communicate in English since English is used as the first international language in countries all over the world. In addition, mastering English for the students of junior high school level is very important since they want to continue their study to a higher level or they want to get a job.

Yet, in fact, students face a lot of problems in mastering the speaking skill. The lack of practice of the language both inside and outside the classroom is the main cause of the students' 
failure in mastering speaking skill. Besides, the very limited time is also considered to support the failure of the students' speaking skill since the English lesson at school is usually held just for four hours per week which is divided into two meetings. One meeting lasts for 80 minutes. Schools apply the integrated teaching of English consisting of listening, speaking, reading, and writing. Consequently, the proportion of teaching speaking is very limited because it is integrated with the other three language skills. Since the time for teaching speaking is very limited, the English teacher is expected to be able to make use the available time more effectively and efficiently by applying a certain strategy that can encourage students to actively participate in the speaking class. This seems to be a real condition faced by most students in Indonesia. This condition is also faced by the students at Islamic junior high school in learning English, especially in mastering speaking skill.

Dealing with this reality, the English teacher is supposed to try to apply a different way in teaching speaking in which one of them is by using technology. As stated by Parveen (2016), technology helps and encourages the playfulness of learners and involves them in a different way of learning. Technology gives learners a chance to engage independently, provides opportunities for self-paced interactions, privacy, and a safe environment where mistakes are corrected and exact feedback is given. Feedback helps the learners to exercise and focus on particular error which adds additional value by its ability. One of the technologies that can be used by teachers is Multimedia Presentation

Hence, this study focuses more on using multimedia presentation in the form of PowerPoint slides to improve students' speaking skills in the form of recount genre. Male (2003) says that the use of the computer as a learning tool makes or influences students' focus, engagement, and product during the teachinglearning process. In the same vein, Wang and Gearhart (2006) state that visuals are often more effective than words to express an idea or arouse emotion.

\section{METHOD}

The design of this study is categorized into Collaborative Classroom Action Research (CAR) since it meets the criteria of classroom action research. In Classroom Action Research, initially, a researcher identifies problems which happen in teaching-learning process, then sets the plan, designs a way to solve problems, and implements the plan. Therefore, the researcher focuses on a particular classroom aiming at finding the solution for the problems occur. In conducting the study, the researcher is helped by one of the English teachers of Islamic junior high school as a collaborator. Kemmis and McTaggart (1988) assert that action research is collaborative when the researcher works together with his colleague from the beginning until the end of the research activities. The design of the present study follows the procedure of Action Research proposed by Kemmis and McTaggart which stated that action research involves selfreflective spirals of planning, acting, observing, and reflecting.

This Classroom Action Research (CAR) is conducted at MTs Al-Islam Nganjuk Regency East Java, Indonesia. The subjects are eighth graders consisting of two parallel classes, class A and class B. The subject of this study is 14 students of class A. The school is facilitated by one multimedia room.

The data were collected through questionnaire, observation sheets, interview, and field notes. The use of questionnaire helps the researcher to gather clear and concisely structured feedback from the students about their attitude toward the strategy implemented. The type of questions used in the questionnaire is multiple choice questions in which each item provides four different alternative options ( $a, b$, c, d) to choose. There are five items on the questionnaire which may lead the researcher to come to a conclusion about the students' attitude. The result of the questionnaires is to reinforce data on the students' active involvement gained from the observation sheets.

The observation sheets are used to gather data about the students' involvement in the teaching and learning activities. The technique of observation used are participant observation in which the researcher as a part of the action involved in doing observation and nonparticipant observation means that the observation is done by a collaborator who is sitting somewhere in the classroom, silent, but attentive to observe the students' involvement in the action. In this case, the observer fills in the observation checklist by putting a tick $(\sqrt{ })$ on one of the four indicators.

Moreover, the use of field notes is also very helpful for keeping a record of what happens, of why and where ideas evolved and the research process itself. Thus, field notes refer to written 
account of what the researcher hear, see, experience, and think in the course of collecting, evaluating, and reflecting on the data which might not be covered in the observation sheets, the students' self-assessment sheet, and the questionnaires. There are three points covered in field notes, namely general point, good point, and point to improve.

\section{RESULTS AND DISCUSSION}

Since this study is conducted in two cycles, the discussion of the findings will be divided into two sections, namely Cycle 1 and Cycle 2 .

\section{Cycle 1}

Cycle 1 was carried out and conducted in three meetings with the time allotted $2 \times 40$ minutes for each meeting. The text given was a recount entitled "Recreation, sport, and my sister's activity". The topic was chosen since it suited to the topic taught based on the regular schedule. Here, the researcher used Multimedia Presentation as the instructional media. The researcher used the scoring rubric as the instrument to measure the students' speaking performance. Meanwhile, the observation checklist was used to get data about students' involvement during the teaching-learning process. In addition, questionnaire and field notes were used as supporting data related to those two criteria above.

\section{Students' speaking performance}

In analyzing the students' speaking performance, the researcher used an analytic scoring rubric adapted from Ur (1996). The students' speaking performances scores are presented in Table 1.

Table 1. Students' speaking performance score

\begin{tabular}{cccc}
\hline No & Score Range & Number of Students & Percentage \\
\hline 1 & $80-100$ & 1 & $7.14 \%$ \\
2 & $70-79$ & 1 & $7.14 \%$ \\
3 & $60-69$ & 3 & $21.43 \%$ \\
4 & $50-59$ & 4 & $28.57 \%$ \\
5 & $0-49$ & 5 & $35.72 \%$ \\
\hline \multicolumn{2}{r}{} \\
\hline
\end{tabular}

Based on the data, it can be seen that one student (7.14\% of the students) achieved a score range of $80-100$. There was one student $(7.14 \%$ of the students) who achieved the score in the range of 70-79. There were three students ( $21.43 \%$ of the students) who achieved the score range of 60-69. There were four students ( $28.57 \%$ of 14 students) who achieved the score in the range 50-59. Meanwhile, there were five students $(35.72 \%$ of the students) who achieved the score in the range $0-49$.

Table 2. Students' speaking performance score in each aspect

\begin{tabular}{clcc}
\hline Aspect & \multicolumn{1}{c}{ Indicator } & $\begin{array}{c}\text { Number of } \\
\text { Students }\end{array}$ & Percentage \\
\hline \multirow{5}{*}{ Fluency } & Little or no communication & 2 & $14.28 \%$ \\
& $\begin{array}{l}\text { Very hesitant and brief utterances, sometimes } \\
\text { difficult to understand }\end{array}$ & 6 & $42.85 \%$ \\
& $\begin{array}{l}\text { Get ideas across, but hesitantly and briefly } \\
\text { Effective communication in short turns }\end{array}$ & 4 & $28.57 \%$ \\
& $\begin{array}{l}\text { Easy and effective communication, uses a } \\
\text { long turn }\end{array}$ & 0 & $14.28 \%$ \\
& $\begin{array}{l}\text { Little or no language produced } \\
\text { Poor vocabulary, mistakes in basic grammar, } \\
\text { may have a very strong foreign accent }\end{array}$ & 3 & $0 \%$ \\
$\begin{array}{l}\text { Adequate but not rich vocabulary, makes } \\
\text { obvious grammatical mistakes, slight foreign }\end{array}$ & 3 & $21.43 \%$ \\
$\begin{array}{l}\text { accent } \\
\text { Good range of vocabulary, occasional } \\
\text { grammar slips, slight foreign accent }\end{array}$ & 1 & $50 \%$ \\
Wide vocabulary appropriately used, virtually \\
no grammar mistakes
\end{tabular}


In the aspect of fluency, two students (14.28 $\%$ of 14 students) were in "little communication" category. There were six students $(42.85 \%$ of 14 students) who were in "very hesitant and had brief utterances, sometimes difficult to understand" category. There were four students ( $28.57 \%$ of 14 students) who "got ideas across, but hesitantly and briefly". Then, there were 2 students (14.28\% of 14 students) in "effective communication in short-turn" category and no student was in "easy and effective communication" category. In addition, in this cycle, one student was absent (TS) in the first meeting.

In terms of accuracy, three students $(21.43 \%$ of 14 students) produced "little language". There were three students (21.43\% of 14 students) was "poor vocabulary, mistakes in basic grammar, may have a very strong foreign accent". There were seven students (50\% of 14 students) who had "adequate vocabulary, made obvious grammatical mistakes, slight foreign accent". Also, there was one student $(7.14 \%$ of 14 students) had a "good range of vocabulary, occasional grammar slip, slight foreign accent". Meanwhile, no student spoke with wide vocabulary appropriately used, virtually no grammar mistakes.

The score on each student's speaking performance is obtained from the indicators of both fluency and accuracy. The score is summed up and then divided by maximum score and multiplied by one hundred. From the data, it was known that there were nine students out of 14 students who passed the Minimum Passing Grade $(K K M)$. It means that the percentage of the students' speaking performance in this cycle was $64.29 \%$. This means that the first criterion of success in this cycle has not been achieved yet and the research was necessary to continue to cycle 2.

\section{Students' involvement}

In obtaining the data on the students' involvement in the teaching-learning process, observation checklist and field notes were utilized. The observation checklist consisted of four indicators or items which should be done by the students, they are: 1) asking questions for clarification frequently; 2) responding to and or answering the teacher's instruction and questions; 3 ) doing the task(s) by making brief notes actively; and 4) helping and or asking for help from each other. Meanwhile, field notes were used to cover things which were uncovered in the observation checklist.

The observation was done during the implementation of this strategy. The criterion determined for the students' involvement was $100 \%$ of the students achieve at least the "active enough stage". In this case, the students are considered as active if they do two out of four indicators in the observation checklist. Table 3 shows the students' involvement based on the indicators of the observation checklist.

Table 3. Students' involvement

\begin{tabular}{|c|c|c|c|c|c|c|c|}
\hline \multirow{2}{*}{ No } & \multirow{2}{*}{ Indicator } & \multirow{2}{*}{$\begin{array}{l}\text { Number of } \\
\text { Students who } \\
\text { Fulfilled the } \\
\text { Indicators }\end{array}$} & \multirow{2}{*}{$\begin{array}{l}\text { Percen } \\
\text { tage }\end{array}$} & \multicolumn{4}{|c|}{$\begin{array}{l}\text { Number and percentage of } \\
\text { Students who Get Category }\end{array}$} \\
\hline & & & & $\begin{array}{c}\text { Not } \\
\text { Active }\end{array}$ & $\begin{array}{l}\text { Active } \\
\text { Enough }\end{array}$ & Active & $\begin{array}{l}\text { Very } \\
\text { Active }\end{array}$ \\
\hline 1. & $\begin{array}{l}\text { Asking questions for } \\
\text { clarification frequently }\end{array}$ & 8 & $57.14 \%$ & & & & \\
\hline 2. & $\begin{array}{l}\text { Responding to and or } \\
\text { answering the teacher's } \\
\text { instruction and questions }\end{array}$ & 13 & $92.86 \%$ & 0 & 6 & 6 & 2 \\
\hline 3. & $\begin{array}{l}\text { Doing the task(s) by making } \\
\text { brief notes actively }\end{array}$ & 10 & $71.43 \%$ & $0 \%$ & $4286 \%$ & 42.86 & 14.28 \\
\hline 4. & $\begin{array}{l}\text { Helping or and asking for } \\
\text { help from each other }\end{array}$ & 7 & $50 \%$ & & & $\%$ & $\%$ \\
\hline
\end{tabular}

As presented in Table 3, the result of the data analysis showed that there was no student who was "not active" ( $0 \%$ of 14 students). There were six students $(42.86 \%$ of 14 students) who were categorized as "active enough". There were also six students (42.86\% of 14 students) that fell into the "active" category and two students
( $14.28 \%$ of all students) were categorized "very active".

Furthermore, in this cycle, there were eight students (57.14\% of 14 students) that fell into the category of "asking questions for clarification" frequently. 13 students $(92.86 \%$ of 14 students) were responding to and or answering the teacher's instruction and 
questions. There were 10 students $(71.43 \%$ of the students) who were doing the task(s). Only seven students $(50 \%$ of the students) were helping and or asking for help from each other.

Field notes revealed some points, general points, good points, and points to improve in the implementation of Multimedia Presentation Strategy in the teaching and learning of speaking. In the pre-teaching activity, the teacher explained what was going to be done and all the students could easily understand the instruction. This is a general point. In the post-teaching, some of the students could do the task(s) well. Besides, they were brave to speak louder and did not care when their friends laughed at them. This is a good point. In whilst-teaching, the male students played much and sometimes they did not understand the teachers' instruction. This is a point to improve.

To sum up, the result of the data analysis from the two sources of data, especially the observation checklist, indicated that the second criterion of success was not been achieved yet. It was not achieved been yet since the percentage of the active involvement (active + very active+ active enough) in the observation checklist was not $100 \%$. Thus, the researcher needed to continue to the next cycle because the first criterion of success has not been achieved yet.

\section{Cycle 2}

This section presents the findings found throughout Cycle 2. It covered the data of the findings on the students' speaking performance and the students' involvement. The same as that in Cycle 1, the researcher used the scoring rubric as the instrument to measure the students' speaking performance. Meanwhile, the researcher employed observation checklist to achieve the data about students' involvement during the teaching-learning process. In addition, questionnaire and field notes were used as supporting data related to those two criteria.

\section{Students' speaking performance}

From the analysis of the students' speaking performance, it was found that there was a significant improvement of the students' speaking performance, although some of them still made mistakes on some language elements being observed, namely fluency and accuracy. The score of the students' speaking performance in Cycle 2 can be seen in Table 4.

Table 4. Students' speaking performance score

\begin{tabular}{cccc}
\hline No & Score Range & Number of Students & Percentage \\
\hline 1 & $80-100$ & 6 & $42.86 \%$ \\
2 & $70-79$ & 1 & $7.14 \%$ \\
3 & $60-69$ & 3 & $21.43 \%$ \\
4 & $50-59$ & 4 & $28.58 \%$ \\
5 & $0-49$ & 0 & $0 \%$ \\
\hline & Total & 14 & $100 \%$ \\
\hline
\end{tabular}

Based on the data, it can be seen that six students $(42.86 \%$ of the students) achieved a score range of $80-100$. There was one student (7.14\% of the students) who achieved the score in the range of 70-79. There were three students ( $21.43 \%$ of the students) who achieved the score range of 60-69. There were four students (14.29\% of 14 students) who achieved the score in the range of 50-59. Meanwhile, there were no students ( $0 \%$ of the students) who achieved the score range in the range of $0-49$.

The data in Table 5 construed that in term of fluency in this cycle; no student fell into the category of "speechless or did not talk anything". Three students $(21.43 \%$ of 14 students) fell into the category of "very hesitant and brief utterances, sometimes difficult to understand". There were four students $(28.57 \%$ of 14 students) who fell into the category of "got ideas across, but hesitantly and briefly". Then, there were five students ( $35.71 \%$ of 14 students) who fell into the category of "effective communication in short turn" and there were two students (14.28\% of 14 students) who fell into the category of "had easy and effective communication". In addition, in cycle 2 , no student was absent.

Table 5. Students' speaking performance score in each aspect

\begin{tabular}{clcc}
\hline Aspect & \multicolumn{1}{c}{ Indicator } & $\begin{array}{c}\text { Number of } \\
\text { Students }\end{array}$ & Percentage \\
\hline \multirow{2}{*}{ Fluency } & Little or no communication & 0 & $0 \%$ \\
& Very hesitant and brief utterances, sometimes & 3 & $21.43 \%$
\end{tabular}




\begin{tabular}{|c|c|c|c|}
\hline & difficult to understand & & \\
\hline & Get ideas across, but hesitantly and briefly & 4 & $28.57 \%$ \\
\hline & Effective communication in short turns & 5 & $35.71 \%$ \\
\hline & $\begin{array}{l}\text { Easy and effective communication, uses a long } \\
\text { turn }\end{array}$ & 2 & $14.29 \%$ \\
\hline & Little or no language produced & 0 & $0 \%$ \\
\hline & $\begin{array}{l}\text { Poor vocabulary, mistakes in basic grammar, } \\
\text { may have a very strong foreign accent }\end{array}$ & 3 & $21.43 \%$ \\
\hline Accuracy & $\begin{array}{l}\text { Adequate but not rich vocabulary, makes } \\
\text { obvious grammatical mistakes, slight foreign } \\
\text { accent }\end{array}$ & 5 & $35.71 \%$ \\
\hline & $\begin{array}{l}\text { Good range of vocabulary, occasional grammar } \\
\text { slips, slight foreign accent }\end{array}$ & 4 & $28.57 \%$ \\
\hline & $\begin{array}{l}\text { Wide vocabulary appropriately used, virtually } \\
\text { no grammar mistakes, }\end{array}$ & 2 & $14.29 \%$ \\
\hline
\end{tabular}

In terms of accuracy, no student was in "little or no language produced" category. There were three students ( $21.43 \%$ of the students) were in "poor vocabulary, mistakes in basic grammar, may have a very strong foreign accent" category. There were five students (35.71\% of 14 students) in "adequate vocabulary, made obvious grammatical mistakes, slight foreign accent" category. Then, there were four students $(28.57 \%$ of 14 students) in a "good range of vocabulary, occasional grammar slip, slight foreign accent" category. In addition, there were two students (14.28\% of 14 students) in "spoke with wide vocabulary appropriately used, virtually no grammar mistakes" category.

Since the percentage of the students who got a score in the rank of 50-100 was $100 \%$, it can be said that the first criterion of success in this research was achieved and the cycle of the research was stopped.

\section{Students' involvement}

In obtaining the data on the students' involvement in the teaching-learning process, observation checklist and field notes were utilized. The indicators used in observation checklist were the same as in Cycle 1 . Meanwhile, field notes were used to cover things which were uncovered in the observation checklist. The observation was done during the implementation of this strategy. The criterion determined for the students' involvement was $100 \%$ of the students achieve at least the "active enough" category. In this case, the students are considered as active if they do at least 2 out of 4 indicators in the observation checklist. Table 6 shows the students' involvement based on the indicators of the observation checklist.

Table 6. Students' involvement

\begin{tabular}{|c|c|c|c|c|c|c|c|}
\hline \multirow{2}{*}{ No } & \multirow{2}{*}{ Indicator } & \multirow{2}{*}{$\begin{array}{l}\text { Number of } \\
\text { Students who } \\
\text { Fulfilled the } \\
\text { Indicators }\end{array}$} & \multirow{2}{*}{$\begin{array}{l}\text { Percen } \\
\text { tage }\end{array}$} & \multicolumn{4}{|c|}{$\begin{array}{l}\text { Number and percentage of } \\
\text { Students who Get Category }\end{array}$} \\
\hline & & & & $\begin{array}{c}\text { Not } \\
\text { Active }\end{array}$ & $\begin{array}{c}\text { Active } \\
\text { Enough }\end{array}$ & Active & $\begin{array}{l}\text { Very } \\
\text { Active }\end{array}$ \\
\hline 1. & $\begin{array}{l}\text { Asking questions for } \\
\text { clarification frequently }\end{array}$ & 10 & $71.43 \%$ & & & & \\
\hline 2. & $\begin{array}{l}\text { Responding to and or } \\
\text { answering the teacher's } \\
\text { instruction and questions }\end{array}$ & 12 & $85.71 \%$ & 0 & 3 & 9 & 2 \\
\hline 4. & $\begin{array}{l}\text { Doing the task(s) by } \\
\text { making brief notes } \\
\text { actively } \\
\text { Helping or and asking for } \\
\text { help from each other }\end{array}$ & 14 & $35.71 \%$ & $0 \%$ & $21.43 \%$ & $\begin{array}{c}64.29 \\
\%\end{array}$ & $\begin{array}{c}14.28 \\
\%\end{array}$ \\
\hline
\end{tabular}

As shown in Table 6, the result of the data analysis showed that there was no student who was not active. There were three students ( $21.43 \%$ of 14 students) who were categorized "active enough". There were nine students
(64.29\% of 14 students) who were categorized" active and two students (14.28\% of all students) were categorized" very active".

Furthermore, in this cycle, there were 10 students ( $71.43 \%$ of 14 students) that are asking 
questions for clarification frequently. 12 students (85.71\% of 14 students) were responding to and or answering the teacher's instruction and questions. There were 14 students $(100 \%$ of the students) doing the task(s). Only five students (35.71\% of the students) were helping and or asking for help from each other.

Field notes revealed some points, general points, good points, and points to improve in the implementation of Multimedia Presentation strategy in the teaching and learning of speaking. In the pre-teaching activity, the teacher explained what was going to be done and all the students could easily understand the instruction and they pay attention to the teacher's explanation. This is a general point. In the whilst-teaching, the students were enthusiastic in accomplishing the task(s). This is a good point. Some students complain to create monologue many times. This is a point to improve.

From the data, it was known that the percentage of the active involvement (active + very active + active enough) in the observation checklist was $100 \%$. It was the same as the first cycle.

Basically, there are three aspects discussed, namely students' speaking achievement, students' involvement, and students' perception.

First is students' achievement. The implementation of Multimedia Presentation strategy is used to increase students' achievement. In this case, the students' achievement is about the students' speaking skill, especially in recount genre.

The strategy is used to improve students' speaking skill by following its procedure. The procedures are: (1) the teacher explained the form of activities that will be conducted in the speaking class, (2) the teacher showed a set of PowerPoint slides to the students, (3) the teacher told a story based on a set of PowerPoint slides, (4) the teacher asked questions to the students to check students understanding, (5) the teacher divides students into group of three, (6) the students make a story based on the PowerPoint slides in group, (7) one of the students told a story in front of the class, and (8) the students made their own story. In addition, in analyzing students' speaking performance, the researcher used analytic scoring rubric adapted from Ur (1996). The score on each student's speaking performance is obtained from the indicators of both fluency and accuracy. The score is summed up and then divided by maximum score and multiplied by one hundred. From the data, it was known that the percentage of students' speaking performance was $64.29 \%$ (9 students of 14 students) in Cycle 1 and it became 100\% (all students) in Cycle 2.

The second is the students' involvement. The implementation of Multimedia Presentation strategy can also increase students' involvement during the teaching-learning process. In obtaining the data on the students' involvement in the teaching-learning process, observation checklist was utilized. The observation checklist consisted of 4 indicators or items which should be done by the students. The criterion determined for the students' involvement was $70 \%$ of the students achieved at least the active category. In this case, the students are considered as active if they do 3 out of 4 indicators in the observation checklist. From the data, it was known that the percentage of the students' involvement was $100 \%$ (all students) in Cycle 1 and it was also $100 \%$ (all students) in Cycle 2.

In addition, the researcher and his collaborator made an improvement and revision of the lesson plan and the media for the second cycle. There were some changes in the lesson plans and the media in Cycle 2 than that in Cycle 1. Related to the lesson plan, the teacher explained the importance of multimedia in daily life in pre-teaching and the teacher explained the characteristic of recount text in Whilst-teaching in Cycle 1. These two learning activities were not done anymore in Cycle 2. The time allotment was used to discuss related vocabulary. It was done because, during the implementation of Cycle 1, the researcher and his collaborator noticed that one of the students' difficulties in speaking was caused by limited vocabulary. Another reason is that most of the students have understood the importance of multimedia in daily life and the characteristic of recount text because it has been explained during Cycle 1 . That is why the researcher and his collaborator thought it was not necessary to explain it anymore in Cycle 2.

Meanwhile, in relation to the media used in Cycle 1, the researcher and his collaborator used one or two animations in one slide. Yet, in Cycle 2 , the researcher and his collaborator used more than two animations in one slide. It was done because it seems that the students were getting bored soon during the implementation of the strategy. Thus, using only one animation in one slide can be called not accurate and not well designed yet. That is why the researcher and his 
collaborator tried to use animation accurately and well designed by adding the number of animations in a slide. Then, in Cycle 1, the researcher and his collaborator did not use sound as media, but in Cycle 2, the researcher and his collaborator used sound as additional media in implementing the strategy. The sound was related to the animation, for example when the animation was about a woman sang a song and musical equipment, we equipped with related sound during the implementation of this strategy.

The third is students' perception. In relation to the students' perception, the data were collected by using a questionnaire distributed to the students. The questionnaire consists of 5 questions in which there were four options provided for each question. Table 7 shows the students' perception of the use of Multimedia Presentation strategy in teaching speaking.

Table 7. The result of students' perception

\begin{tabular}{cccccc}
\hline \multirow{2}{*}{ No. } & \multirow{2}{*}{ Questions } & \multicolumn{2}{c}{ Interesting (a and b) } & \multicolumn{2}{c}{ Not Interesting (c and d) } \\
\cline { 3 - 5 } & & Frequency & Percentage & Frequency & Percentage \\
\hline 1. & Item 1 & 14 students & $100 \%$ & 0 student & $0 \%$ \\
2. & Item 2 & 14 students & $100 \%$ & 0 student & $0 \%$ \\
3. & Item 3 & 12 students & $85.72 \%$ & 2 students & $14.28 \%$ \\
4. & Item 4 & 12 students & $85.72 \%$ & 2 students & $14.28 \%$ \\
5. & Item 5 & 14 students & $100 \%$ & 0 student & $0 \%$ \\
Average & & $94.29 \%$ & & $5.71 \%$ \\
\hline
\end{tabular}

Based on Table 7, it was found that the students gave positive responses towards the implementation of Multimedia Presentation strategy in teaching English, especially teaching speaking.

\section{CONCLUSION}

On the basis of the findings of the action research conducted in two cycles, it can be concluded that Multimedia Presentation strategy can improve the students' speaking skills in terms of their skill in pronouncing English words and can increase the students' involvement during the teaching-learning process as well as students' interest.

Based on the results of the data analysis, it was shown that the Multimedia Presentation strategy was successful to improve students' speaking skills. Besides, Multimedia Presentation strategy also gives positive impact on the students' involvement in the instructional process in which Multimedia Presentation implemented. The implementation of Multimedia Presentation strategy in speaking class can increase the students' involvement in the teaching-learning process. It is proven from the result of the research which shows that the percentage of the students' involvement during the implementation Multimedia Presentation strategy increases after the implementation of Multimedia Presentation strategy.

\section{REFERENCES}

Burns, A. \& Joice, H. (1993). Focus on speaking $\left(2^{\text {nd }}\right.$ edition). Sydney: Macquarie University.

Kemmis, S., \& McTaggart, R. (1988). The action research planner. Gee Long: Deakin University Press.

Male, M. (2003). Technology for inclusion. USA: Pearson Education Group.

Nunan, D. (1989). Designing tasks for the communicative classroom. Cambridge: Cambridge University Press.

Parveen, B. W. (2016). Use of technology in improving speaking skills. Journal of English Language and Literature (JOELL), 3(2).

Pusat Kurikulum (Puskur). (2006). Standar isi bahasa Inggris (Content standard for English). Jakarta.

Richards, J. C., \& Renandya W. A. (Eds). (2002). Methodology in language teaching: An anthology of current practice. Cambridge: Cambridge University Press.

Spratt, M., Pulverness, A., \& Williams, M. (2005). The TKT (Teaching Knowledge Test) course. Cambridge: Cambridge University Press.

Ur, P. (1996). A course in language teaching: Practice and theory. Cambridge: Cambridge University Press.

Wang, H., \& Gearhart, D. L. (2006). Designing and developing web-based instruction. New Jersey: Pearson Education Inc. 